\title{
COORDINATION OF RESPIRATION AND SWALLOWING: functional pattern and relevance of vocal folds closure
}

\author{
Milton Melciades Barbosa COSTA ${ }^{1}$ and Eponina Maria de Oliveira LEMME ${ }^{2}$
}

\begin{abstract}
Context - Breathing and swallowing coordination, despite the expressive number of study, remain as theme deserving further research. Objectives - To identify a coordination pattern between swallowing and the natural breathing pause that occur in association with it (swallowing apnea) and also the relevance of the vocal folds closure in this process. Methods - Sixty-six adults, male and female, including normal health people, post-laryngectomy individuals and patients with digestive complaints without dysphagia were analyzed. The respiratory air flux interruptions produced by wet requested swallows and dry, requested and spontaneous swallows, were registered using thermo and piezoelectric receptors coupled to synectics medical manometry equipment, using Polygram upper 4.21 software. The results were analyzed with the Chi-square $(3 \times 2)$ and $(2 \times 2)$ nonparametric independency test with $P=0.05$. Results - Swallowing apnea is a preventive breathing stop that start just before and stay present during all deglutition pharyngeal phase. It is a well coordinated phenomena that occur as pattern in association with low elastic resistance of the lung, on the expiratory final phase until inspiration initial phase. This breathing stoppage it is usually followed by a short expiraton preceding a new breathing cycle. The swallow apnea and vocal folds closure are both independents mechanisms. Conclusions - It is possible to suppose that in the subconscious condition, swallowing apnea is integrated under coordination of the same control mechanism that also involves the elastic resistance of the lung.

HEADINGS - Respiration. Deglutition. Apnea. Vocal cords.
\end{abstract}

\section{INTRODUCTION}

Swallowing apnea, is not well understood ${ }^{(19,23)}$. Despite the expressive number of articles about respiration and swallowing coordination, especially in the past 10 years, this theme still has questions deserving further study $(10,24,34,40,47)$.

Respiration and swallowing coordination determines a breathing stop when a swallow takes place. This apnea, together with some anatomical structures, is considered as an important event to provide an effective airway protection during swallowing $(1,8,11,12,21,30,32,33,34,38,39)$.

Swallowing apnea is a brief period in which breathing ceases just before and during all the pharyngeal phase of deglutition ${ }^{(27)}$. The breathing cycle is not simply repressed during swallowing; it is substituted by a different and well-controlled behavior pattern ${ }^{(42)}$. As already observed, variations in the bolus volume $e^{(4,17,18,}$ ${ }^{28)}$ and viscosity $(5,20,29,37,40)$ characteristics will interfere on the breathing stop time duration.

The coordination of breathing and swallowing reveals a well-timed pattern between physiological respiratory events and related swallowing events.
Respiration is halts before the onset of laryngeal elevation usually in association with expiration time ${ }^{(8,28)}$.

The vocal folds closure could be part of a protective mechanism that involves swallowing apnea ${ }^{(34)}$. This apnea begins when the vocal folds are maximally adducted and ends when these folds begin to reopen supporting the idea that swallow apnea could be related to glottis closure $^{(41)}$. The pressure level between the vocal folds begins to rise and remains high throughout the swallow pharyngeal phase. In the trachea, the pressure first decreases and then increases to just over the resting basal level ${ }^{(44)}$.

The swallowing-related respiratory pause is elicited during oral phase just before of the pharyngeal phase as a mechanism that triggers a laryngeal exclusion reflex $^{(9,13)}$. In human, the closure of the larynx during swallowing is a protective reflex that could be elicited by a conscious decision ${ }^{(13)}$.

Under conscious decision humans are able to swallow and stop a breathing cycle whenever required. In this way, to swallow with a large lung air volume, high lung elastic resistance, in association with vocal folds closure could reinforce the airway protective mechanism as

'Laboratório de Motilidade Digestiva, Departamento de Anatomia do Instituto de Ciências Biomédicas, Universidade Federal do Rio de Janeiro (UFRJ); ${ }^{2}$ Divisão de Gastroenterologia, Hospital Universitário Clementino Fraga Filho da UFRJ, Rio de Janeiro, RJ, Brazil.

Correspondence: Dr. Milton M.B. Costa - Laboratório de Motilidade Digestiva e Imagem, Departamento de Anatomia, Universidade Federal do Rio de Janeiro ICB/CCS UFRJ - 21941-590 - Rio de Janeiro, Brazil, E-mail: mcosta@acd.ufr..br 
proposed by supraglottic and super-supraglottic maneuvers ${ }^{(2,}$ 3,7). Nevertheless, under subconscious control, humans do not swallow in association with deep inspiration. The swallowing apnea occurs almost exclusively at the final stage of expiration, when there is low elastic resistance into the lungs ${ }^{(8,9,28,45)}$.

The swallowing apnea has been defined as a "preventive apnea"(9). The breathing stop and vocal folds closure occur without any discomfort. On the other hand, a laryngeal vestibule direct stimulation produce a reflex apnea with abrupt vocal folds closure producing breathing discomfort and expiratory effort similar to a cough ${ }^{(22,35)}$. This abrupt apnea is better defined as a "defensive apnea". There is general agreement that defensive apnea depends primarily of the vocal folds closure $^{(42,44)}$. Nevertheless, there is no consensus about vocal folds closure associated with the preventive one $\mathrm{e}^{(6,8,19,33,41)}$.

The aim of this study is to identify a breathing interruption pattern in association with swallowing and also the possible role of the vocal folds closure in the swallow apnea.

\section{METHODS}

This study was conducted in full agreement with the ethical guidelines adopted by the 18th World Medical Association (WMA), Declaration of Helsinki, Finland, June 1964; amended by $48^{\text {th }}, 1996$ and $52^{\text {nd }}$ WMA General Assembly, Edinburgh, Scotland, October 2000, in Washington 2002, and Tokyo 2004. The patients who had undergone manometric examinations gave previous consent to use the exam results for teaching and research without disclosing their identities. The laryngectomized patients and the volunteers were informed of the procedures and purpose of this study and gave their written consent.

The breathing and swallow associations (swallowing apnea) were studied in 66 adults, male or female, including normal health people, post-laryngectomy individuals, and patients with digestive complaints. The 66 individuals did not present dysphagia, breathing complaints, or any interferential pathology. These individuals were subdivided into three groups:

1. Patients -50 patients undergoing manometry indicated by esophageal motor disturbance and gastroesophageal reflux disease were enrolled. Of these, 23 patients were males and 27 females aged between 26 and 76 years. From this group, 1,641 breathing pause associated with swallow were analyzed.

2. Volunteers -11 healthy volunteers, 6 males and 5 females aged between 19 and 51 years were enrolled. From this group, 166 breathing pause associated with swallow were analyzed.

3. Laryngectomized - five males who had undergone total laryngectomy more than 2 years earlier, aged between 59 and 84 were enrolled. From this group, 109 breathing pause associated with swallow association were analyzed.

Fifty patients' exams data were selected from the esophageal manometric files in which channels 2 and 8 were active as part of the used methodology. The present study was planned after this selected group had been examined; consequently, there was no possible conscious interference in the observed results by the physicians and patients.
Patients had been examined on dorsal decubitus with a minimum positive inclination, as a standard for the perfusion esophageal manometry, using dry (saliva) and wet ( $5 \mathrm{~mL}$ of water) swallowing requests.

The healthy volunteers and laryngectomized persons were studied in a sitting position using dry (saliva) and wet $(5 \mathrm{~mL}$ of water) swallowing requests. They were previously informed concerning the intention of the research and instructed to swallow in their own time after a command, "from now you may swallow".

The swallow apnea was registered using a piezoelectric receptor and a thermistor coupled with the Synectics Medical computerized manometry equipment with Polygram upper 4.21 software. The piezoelectric receptor (channel 2) registers the activity produced by the mechanical disturbance on the cervical surface determined by swallowing effort. The thermistor (channel 8) registers the temperature variations of the inspired and expired air.

The relationship between breathing and swallow was registered and analyzed in curves time related. This relationship can be found by the perpendicular line drawn by the software.

On patients and volunteers groups, the piezoelectric receptor was placed above the larynx (lateral cervical surface) in the resting position and was considered as well placed because the mechanical disturbance of the swallow produced by the hyoid and laryngeal displacement were clearly observed on the display.

In the laryngectomized group, the piezoelectric receptor was placed over the greater horn of the hyoid bone in the resting position, which was found to be the best position to obtain the mechanical disturbance information from the swallow effort.

On patients and volunteers groups, the thermistor was placed in front of the nostril, where the free airflow was detected, whereas for the laryngectomized group it was placed in front of the tracheostomy. (Figure 1)

The thermistor registers the breathing cycle. Without swallow waves, with positive (up) and negative (down) components can be observed. The positive component represents the expiration, when the air is hotter and the negative one represents inspiration, when the air is colder. With swallowing there is a breathing pause. The hot/cold cycle stops and the absence of the temperature variation shows a curve enlargement with gently cursor movement to the base line direction, until the hot/cold cycle is reactivated by new breathing cycle. The respiratory positive (expiration) and negative (inspiration) components represents the lung elasticity information. On inspiration, the lung is elastically distended receiving energy and on expiration, the stored energy in the elastic fibers is liberated (Figures 2 and 3).

In order to provide a recommended period of adjustment to the apparatus, including adaptation of the receptors, both the volunteers and laryngectomized patients waited about 5 minutes before to start the exam.

Each requested swallow is marked by the operator as dry swallowing (saliva), with a "d" and water swallowing (wet), with a "w". All breathing/swallow association without any letter, indicate a dry no-requested swallow. 


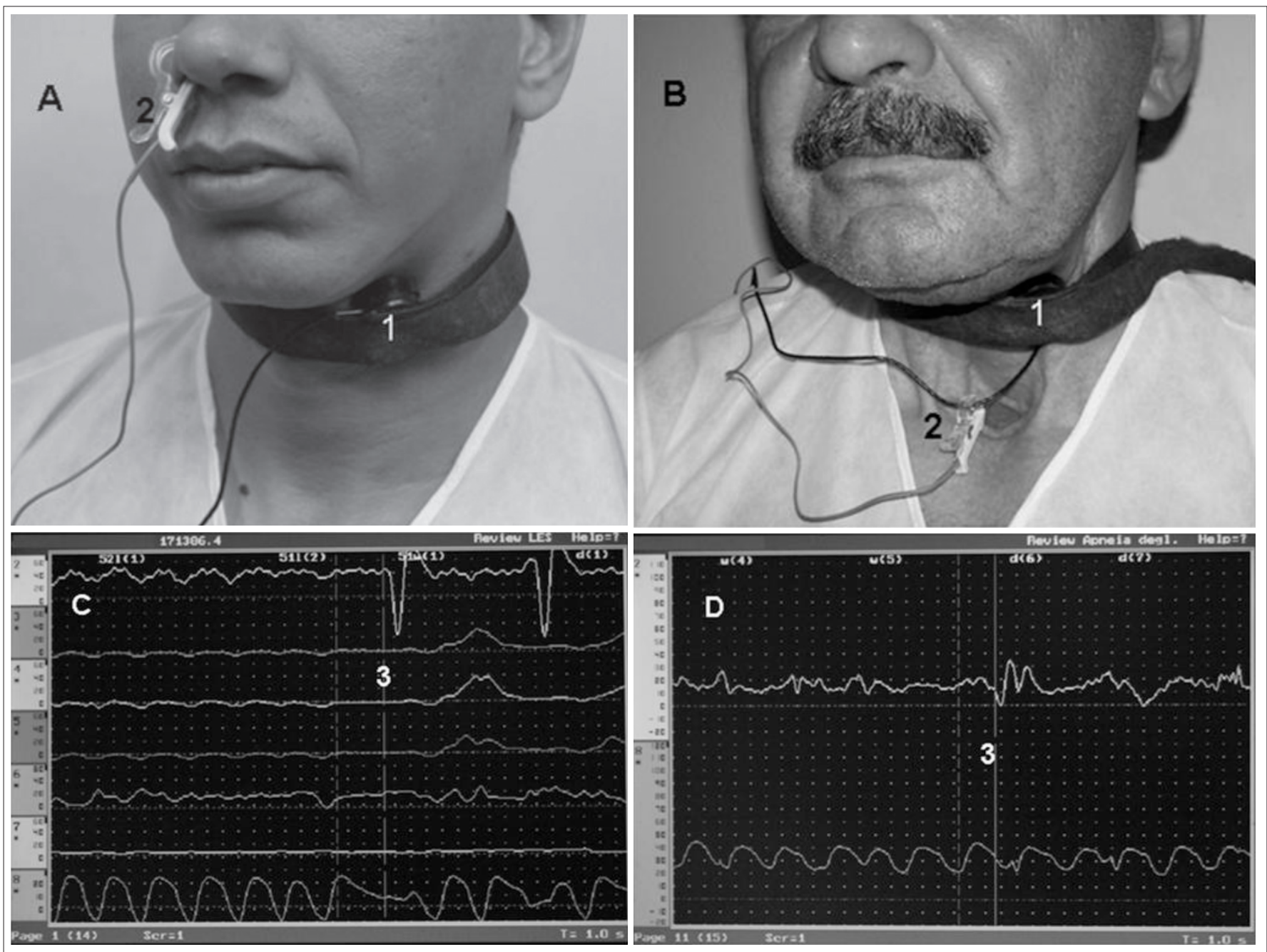

FIGURE 1. The piezoelectric (1) and thermistor (2) apparatus on a nonlaryngectomized individual (A) and a laryngectomized individual (B). In (C), the patient graph and (D) the laryngectomized graph show the correlation with a vertical line (3) between channel 2 (piezoelectric receptor) and channel 8 (the air flux temperature receptor)

\section{Statistical analysis}

Chi-square $\left(\chi^{2}\right)(3 \times 2)$ and $(2 \times 2)$ nonparametric independency test with $P=0.05$ were obtained using Statistica for Windows, StatSoft, Inc. (1996) (http://www.statsoftinc.com).

The statistical analysis of data was done as follow:

1. $\chi^{2}(3 \times 2)$ from the three analyzed groups (volunteers, laryngectomized persons, and patients) against the elastic resistance of the lungs (low and high). $H_{0}$, the swallowing apnea in the low or high moment, is independent of the tested group.

2. $\chi^{2}(3 \times 2)$ from the three analyzed group involving the three swallowing conditions (dry, wet, and unrequested) against the elastic resistance of the lungs (low and high). $H_{0}$, the swallowing apnea in the low or high moment, is independent of the swallow condition.

3. $\chi^{2}(2 \times 2)$ from the three analyzed group involving the elastic resistance of the lungs (low and high) obtained against imperative (patients) and non imperative command (volunteers plus laringectomized) $H_{0}$, the swallowing apnea in low or high moment is independent of the command kind.

4. $\chi^{2}(2 \times 2)$ involving the elastic resistance of the lungs (low and high) against vocal folds presence (volunteers) and absence (laryngectomized). $H_{0}$, the swallowing apnea in the low or high moment, is independent of the vocal folds.

5. $\chi^{2}(2 \times 2)$ involving complementary expiration presence (yes or no) against vocal folds presence (volunteers) and absence (laryngectomized). $H_{0}$, the complementary expiration, is independent of the vocal folds.

6. $\chi^{2}(2 \times 2)$ from volunteer and laryngectomized persons, involving the elastic resistance of the lungs (low and high) against swallowing condition (dry, unrequested, and wet), considering unrequested swallow as dry one. $H_{0}$, swallowing apnea in the low or high moment, is independent of the swallow condition. 


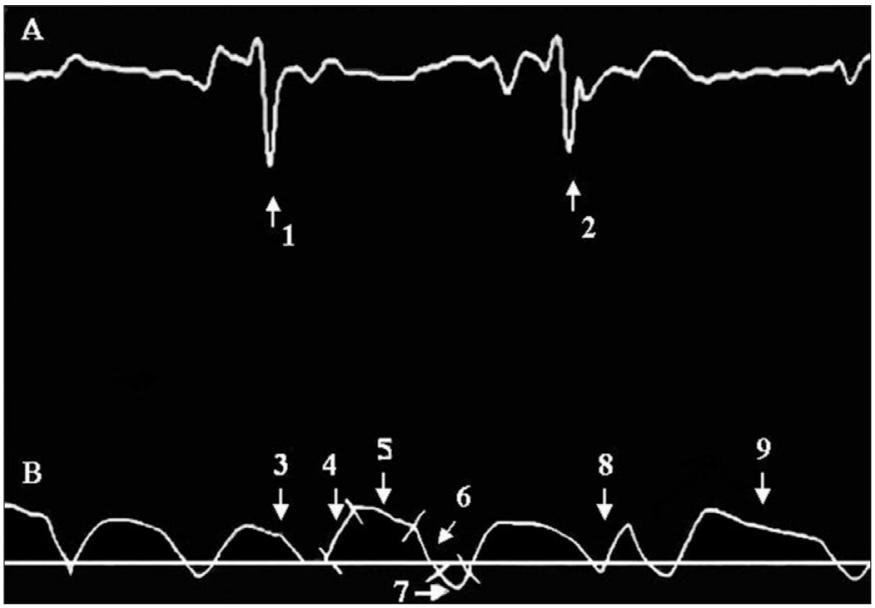

FIGURE 2. Image obtained from nonlaryngectomized individual with its background cleaned where (A) piezoelectric activity (B) breathing curve is determined by thermic variation in the inspired and expired air. A and B are linked curves where swallow spike (1 and 2) are related to breathing stops (3 and 8) where 8 shows an expressive complementary expiration. In 9, one can see a longer final phase of expiration without association with the spikes determined by swallowing, indicating an apnea associated with swallow attempt or spontaneous apnea. By didactic explanation, 4 is the first half of the initial curve of the expiration phase (high lung resistance), 5 the final phase of expiration (low lung resistance), 6 indicates the initial phase of inspiration (low lung resistance), and 7 the final phase of inspiration (high lung resistance)

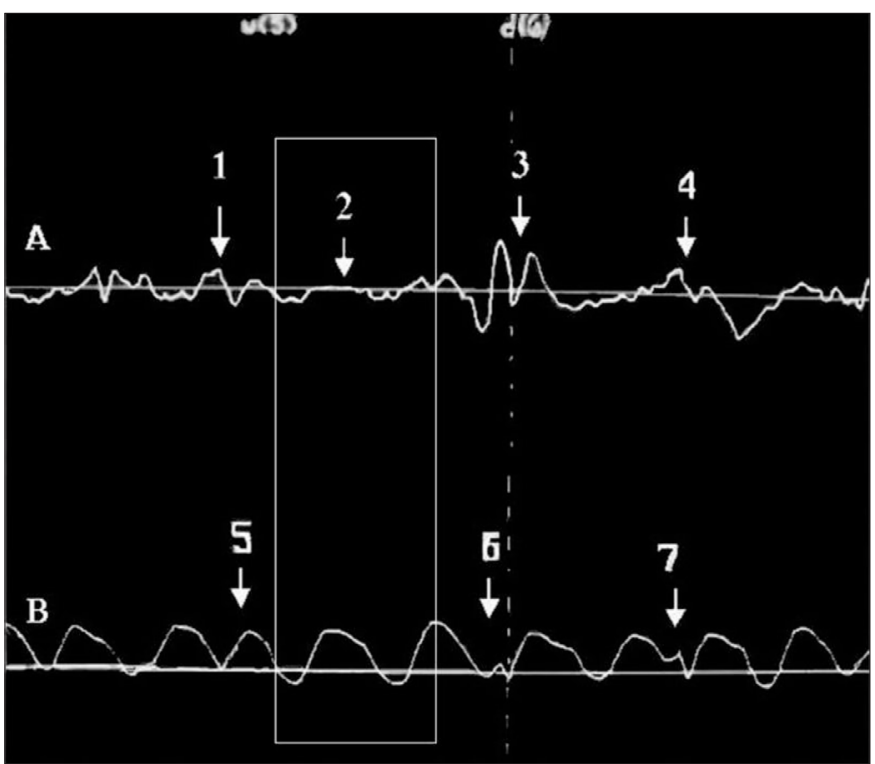

FIGURE 3. Image obtained from laryngectomized individual with its background cleaned, where (A) piezoelectric activity and (B) breathing curve obtained from tracheotomy. In (A), 1, 3, and 4 mark swallowing spikes related in (B) to 5, 6, and 7 breathing stops with complementary expiration where 5 and 7 occur in the final phase of expiration and 6 in the initial phase of inspiration; all of them with low lung elastic resistance. (w) wet and (d) dry on the top of the figure was inserted by the examiner as additional information and as additional guarantees of the $\mathrm{A}$ and $\mathrm{B}$ relation. 2. The rectangle involving the piezoelectric baseline without a swallow movement is related to the regular positive/negative respiratory wave indicates there was no swallow interference in the breathing cycle
7. $\chi^{2}(2 \times 2)$ from volunteers and laryngectomized group, involving complementary expiration presence (yes or no) against swallowing conditions (dry, unrequested, and wet), considering unrequested swallow as dry one. $H_{0}$, the complementary expiration, is independent of the swallow conditions.

\section{RESULTS}

From thermistor and piezoelectric receptors was possible to correlate similarities and differences and to built a table relating the association between the swallowing spike and breathing stop moment ( $\mathrm{L}$ or $\mathrm{H}$ ) with dry, wet, and unrequested swallowing in the volunteer, laryngectomized, and patient groups. The presence $(\mathrm{Y})$ or absence $(\mathrm{N})$ of the complementary expiration associated with dry, wet, and norequested swallow was also registered (Table 1)

TABLE 1. Elastic resistance of the lungs and distribution of complementary expiration for the three analyzed groups considering the swallow kind

\begin{tabular}{|c|c|c|c|c|c|c|}
\hline Volunteers G1 & $\mathrm{L}$ & $\mathbf{H}$ & Total & $\mathrm{Y}$ & $\mathbf{N}$ & Total \\
\hline Dry & 45 & 9 & 54 & 51 & 3 & 54 \\
\hline Wet & 44 & 4 & 48 & 48 & 0 & 48 \\
\hline Unrequested & 59 & 5 & 64 & 61 & 3 & 64 \\
\hline Total & 148 & 18 & 166 & 160 & 6 & 166 \\
\hline$\%$ & 89.16 & 10.84 & 100 & 96.39 & 3.61 & 100 \\
\hline Laryngectomized G2 & $\mathrm{L}$ & $\mathbf{H}$ & Total & Y & $\mathbf{N}$ & Total \\
\hline Dry & 25 & 4 & 29 & 27 & 2 & 29 \\
\hline Wet & 27 & 3 & 30 & 28 & 2 & 30 \\
\hline Unrequested & 47 & 3 & 50 & 39 & 11 & 50 \\
\hline Total & 99 & 10 & 109 & 94 & 15 & 109 \\
\hline$\%$ & 90.83 & 9.17 & 100 & 86.24 & 13.76 & 100 \\
\hline Patients G3 & $\mathrm{L}$ & $\mathbf{H}$ & Total & $\mathrm{Y}$ & $\mathbf{N}$ & Total \\
\hline Dry & 126 & 54 & 180 & 165 & 15 & 180 \\
\hline Wet & 863 & 337 & 1200 & 1170 & 30 & 1200 \\
\hline Unrequested & 199 & 62 & 261 & 241 & 20 & 261 \\
\hline Total & 1188 & 453 & 1641 & 1576 & 65 & 1641 \\
\hline$\%$ & 72.39 & 27.61 & 100 & 96.04 & 3.96 & 100 \\
\hline Total 2 & 1435 & 481 & 1916 & 1830 & 86 & 1916 \\
\hline$\%$ & 74.90 & 25.10 & $100 \%$ & 95.51 & 4.49 & 100 \\
\hline
\end{tabular}

The breathing/swallow association (swallowing apnea) characteristics were similar in both males and females and also in both study positions (dorsal decubitus and sitting position).

The laryngectomized group showed a smaller and irregular swallowing spike complex when compared with the nonlaryngectomized group but there was no difference in the respiratory wave shape and in the associations between the swallow spike and breathing stop comparing laryngectomized and non-laryngectomized groups.

There was no observed association between the swallow spike and breathing stop during the final phase of inspiration or in the first ascending part of the expiration curve. 
The percentage of swallow apnea associated with low elastic resistance of the lung was practically the same in volunteers $(89.16 \%)$ and laringectomized persons $(90.83 \%)$. In the patients group the swallow apnea associated with low elastic resistance of the lung were (72.39\%), approximately $18 \%$ less frequent them that observed in the volunteers and laryngectomized groups.

Considering the all analyzed groups, the percentage of swallow apnea associated with low elastic resistance of the lung was $74.90 \%$ and that associated with high elastic resistance of the lung was $25.10 \%$.

Related with both condition, swallow apnea associated with low or high elastic resistance of the lung, it was usually a complementary expiration following the breathing stop.

Complementary expiration, varying in dimension, was noted, in the three groups. When the apnea occurred at the end of the curve that represents the initial phase of expiration (high elastic resistance of the lungs), the complementary expiration was usually longer than that presented in the final phase of expiration or in the initial phase of inspiration (low elastic resistance of the lungs).

Patients $(96.04 \%)$ and volunteers $(96.39 \%)$ shows, practically, the same percentage of complementary expiration. Nevertheless, in the laryngectomized persons, complementary expiration was present in less frequency $(86.24 \%)$.

The $\chi^{2}$ statistical analysis shows:

1. $\mathrm{H}_{0}$, the swallowing apnea in the low or high moment, is independent of the tested group was rejected $\left(\chi^{2}(3 \times 2)\right.$ $\left.\chi_{0.05 ; 5}^{2}=1041.038 P<0.0000\right)$;

2. $\mathrm{H}_{0}$, the swallowing apnea in the low or high moment, is independent of the swallow condition was accepted $\chi^{2}$ $\left.(3 \times 2) \chi_{0.05: 5}^{2}=10.54321 P<0.061257\right)$;

3. $\mathrm{H}_{0}$, the swallowing apnea in low or high moment is independent of the command kind was rejected (Yates' corrected $\left.\chi^{2} P=0.0000\right)$;

4. $\mathrm{H}_{0}$, the swallowing apnea in the low or high moment, is independent of the vocal folds was accepted (Yates' corrected $\chi^{2} P=0.8073$ );

5. $\mathrm{H}_{0}$, the complementary expiration, is independent of the vocal folds, was rejected (Yates' corrected $\chi^{2} P=0.041$ ).

6. $\mathrm{H}_{0}$, swallowing apnea in the low or high moment, is independent of the swallow condition, was accepted (Yates' corrected $\chi^{2} P=0.8450$ );

7. $\mathrm{H}_{0}$, the complementary expiration, is independent of the swallow conditions, was accepted (Yates' corrected $\chi^{2}$ $P=0.1910)$.

\section{DISCUSSION}

We did not find any difference in shapes registered by piezoelectric or thermistor receptor between men and women, examination position (dorsal decubitus and sitting position) or swallowing conditions (dry or wet) as already described in the literature ${ }^{(18,30,31,36,44)}$.

Age interference in the swallow apnea time was not specifically studied in this paper, although an attempt was made to pinpoint any differences in the registered curves from volunteers group (19 to 51 years old ) and the laryngectomized group's (ages between 59 and 84 years old). Any differences in the apnea pattern based on advanced aged could not be identified as already referred ${ }^{(26,30,31)}$.

All registered swallowing spike were related with breathing stop in the laryngectomized and nonlaryngectomized persons (volunteers and patients).

The same swallow apnea pattern was found in people with and without larynx, show that this preventive apnea it is independent of the vocal folds closure. The vocal folds closure could be an associated but independent action of the swallowing apnea mechanism in agreement with some of the research described in the literature ${ }^{(6,8,12,19)}$ and in disagreement with other ${ }^{(33,41)}$.

The swallow apnea occurred as pattern in association with low elastic resistance of lung in the expiratory final moment or initial inspiratory moment and not only in the expiratory final phase of the breathing cycle as usually considered $^{(18,25,30,36,42)}$.

The swallowing apnea was already observed in the final phase of inspiration and in the initial phase of expiration (high elastic resistance in the lungs) in premature newborns ${ }^{(48)}$. Nevertheless, this observation can not simply be extrapolated to adults, since it is possible that human newborns immaturity affects not only the anatomical structures of respiration, but also the regulatory breathing mechanisms as already considered ${ }^{(14,15,16,33,46)}$

Volume and viscosity increase, are variables that enlarge the swallowing apnea time, as already observed $(4,17,18,20)$. In this paper, these variables were blocked, by use of the same patients protocol with small volume and viscosity in the two added groups. This option were take to compare the patients results, obtained from exams where physicians and patients do not know about research intention against the results from volunteers and laryngectomized previously informed.

It is possible to swallow and to stop the breathing cycle at any moment, but in the subconscious swallow, the breathing pause usually occurs in association with low elastic resistance of the lungs (volunteers $-89.16 \%$, laryngectomized $-90.83 \%$, and patients $-74.90 \%$ ). The discrepant frequency of the breathing pause associated with low elastic resistance of the lung observed in the patient group in relation to the two others, was produced by imperative command that was also responsible for the unexpected statistical rejections.

The unexpected frequency of the swallowing apnea in association with high elastic lung resistance in the patient group $(27.61 \%)$ was dependent on the imperative command usually employed. Patients, with saliva or water in their mouth and hearing "swallow" as an imperative command, respond as quickly as they could. In this manner, the imperative command, sometimes, can interfere and modify the natural answer causing the apnea to take place at an unusual moment. When patient group was excluding, the swallow apnea related with high elastic lung resistance go down to $(10.18 \%)$, show clear influence of the imperative command as statistically observed. 
The complementary expiration is statistically independent of the swallow characteristics (dry or wet) in the compared groups (volunteers and laryngectomized). As pattern, from the three analyzed groups, at end of the swallow apnea, a complementary expiration, with different dimensions were observed before start a new breathing cycle a complementary expiration, with different dimensions were observed. The complementary expiration dimension is influenced by the residual volume of the lungs. The absence of the complementary expiration, excepted to the laryngectomized persons, was interpreted as determined by the breathing pause between expiration and inspiration time, when there is no volume to be exhaled.

In the laryngectomized group the absence of the complementary expiration (13.76\%) was found 4 times more than the two other groups (volunteers 3.61\% and patients $3.96 \%$ ) and explain the statistical dependence found between complementary expiration and vocal folds absence. It is possible that this was because the thermistor sensitivity could not register such a small expiratory volume in front of a tracheostomy, its most critical position. In addition, it is also possible that vocal folds participate secondarily providing additional resistance to expiratory airflow as already demonstrated ${ }^{(44)}$. In this way, the vocal folds closure could have a secondary participation in the swallowing apnea mechanism sustaining the residual air volume to be expired as complementary expiration.

The autonomic mechanism responsible for the interruption of the breathing cycle during swallowing is certainly linked to the elastic resistance of the lungs. Energy is taken up by the elastic tissue of the lungs, determined by thoracic expansion during inspiration and then released during expiration. Consequently, from the final phase of expiration until the start of the inspiration phase, there is little energy stored in the elastic tissue of the lungs, thus, the breathing pause is in a relaxed state and no energy is being spent on sustaining the thorax unnecessarily expanded.

On the basis of these explanations, it is possible to believe that in association with the oral phase, besides classifying food characteristics (volume, viscosity, etc.), one should also classify the elastic resistance of the lungs and integrate all of them as the basis to start the pharyngeal phase. In this way, although swallow apnea and vocal folds closure are both independents mechanisms, it is possible to suppose that in the subconscious condition, they are integrated under coordination of the same control mechanism that also involves the lung elastic resistance.

\section{CONCLUSIONS}

1. The natural breathing stop that start before and stay present during all deglutition pharyngeal phase, swallowing apnea, it is a well coordinated phenomena that occur as pattern in association with low elastic resistance of the lung, on the expiratory final phase until inspiration initial phase, without primary dependence of vocal folds presence. This kind of breathing stoppage is usually followed by a short expiraton preceding a new breathing cycle.

2. The swallow apnea and vocal folds closure are both independents mechanisms. Nevertheless, vocal folds closure could have a secondary participation in the swallowing apnea mechanism sustaining the residual air volume to be expired as complementary expiration.

3. Although swallow apnea and vocal folds closure are both independents mechanisms, it is possible to suppose that in the subconscious condition, they are integrated under coordination of the same control mechanism that also involves the lung elastic resistance.

Costa MMB, Lemme EMO. Coordenação da respiração com a deglutição: padrão funcional e relevância do fechamento das pregas vocais. Arq Gastroenterol. 2010;47(1):42-8.

RESUMO - Contexto - Apesar do expressivo número de estudos sobre a coordenação da respiração com a deglutição, o tema permanece aberto à pesquisa. Objetivo - Identificar um padrão de coordenação entre a pausa respiratória e a deglutição que ocorre em associação a esta usual apneia (apneia de deglutição) e estabelecer a importância do fechamento das pregas vocais que ocorre em associação a esta apneia. Métodos - Foram estudados 66 adultos de ambos os sexos, incluindo voluntários sadios, indivíduos laringectomizados e pacientes com queixas digestivas sem disfagia. Apneias produzidas em associação com deglutições de liquido a pedido e deglutições a seco, solicitadas e espontâneas, foram registradas a partir de informações captadas por termo receptor e receptor piezelétrico acoplados a equipamento de manometria da Synectics Medical usando o software Polygran upper 4.21. Os resultados foram submetidos a teste de independência não paramétricos qui ao quadrado $(3 \times 2)$ e $(2 \times 2)$, com $P=0.05$. Resultados - A apneia de deglutição é uma pausa respiratória preventiva que se inicia imediatamente antes e permanece ativa durante toda a fase faríngea da deglutição. Esta apneia é um bem coordenado fenômeno padrão que ocorre em associação com a baixa resistência elástica dos pulmões, presentes nas fases final da expiração, até a inicial da inspiração. Esta pausa respiratória é usualmente seguida de uma curta expiração que antecede novo ciclo respiratório. A apneia de deglutição e o fechamento das pregas vocais são mecanismos independentes. Conclusões - É possível supor que em atividade subconsciente, a apneia de deglutição seja integrada sob a coordenação do mesmo mecanismo de controle que também envolve a resistência elástica dos pulmões.

DESCRITORES - Respiração. Deglutição. Apneia. Pregas vocais. 


\section{REFERENCES}

1. Ardran GM, Kemp FH, Manen L. Closure of the larynx. Br J Radiol. 1953;310: 497-509.

2. Bülow M, Rolf $\mathrm{O}$, Ekberg O. Videomanometric analysis of supraglottic swallow, effortful swallow and chin tuck in dysphagic patients. Dysphagia. 2001;16:190-5.

3. Bülow M, Rolf O, Ekberg O. Supraglottic swallow, effortful swallow, and chin tuck did not alter hypopharyngeal intrabolus pressure in patients with pharyngeal dysfunction. Dysphagia. 2002;17:197-201.

4. Butler SG, Postma GN, Fischer E. Effects of viscosity, taste, and bolus volume on swallowing apnea duration of normal adults. Otolaryngol Head Neck Surg. 2004;131:860-3.

5. Carnaby-Mann G, Crary M. Pill swallowing by adults with dysphagia. Arch Otolaryngol Head Neck Surg. 2005;131:970-5.

6. Charbonneau I, Lund JP, McFarland DH. Persistence of respiratory-swallowing coordination after laryngectomy. J Speech Lang Hear Res. 2005;48:34-44.

7. Chaudhuri G, Hildner CD, Brady S, Hutchins B, Aliga N, Abadilla E. Cardiovascula effects of supraglottic and super-supraglottic swallowing maneuvers in stroke patients with dysphagia. Dysphagia. 2002;17:19-23.

8. Costa MMB, da Silva RI, Lemme E, Tanabe R. Apnéia de deglutição no homem adulto. Arq Gastroenterol. 1998;35:32-9.

9. Costa MMB. Mecanismos de proteção das vias aéreas. In: Costa MMB, Castro LP, editores. Tópicos em deglutição e disfagia. Rio de Janeiro: MEDSI; 2003. p.163-73.

10. Don GW, Waters KA. Influence of sleep state on frequency of swallowing, apnea, and arousal in human infants. J Appl Physiol. 2003;94:2456-64.

11. Donzelli J, Brady S. The effects of breath-holding on vocal fold adduction: implication for safe swallowing. Arch Otolaryngol Head Neck Surg. 2004;130: 208-10.

12. Fink BR. The human larynx: the functional study. New York: Raven Press; 1975

13. Fink BR. Bioenergetical foundations of consciousness. In: Hameroff SR, Kasniak AW, Scoot AC, editors. Toward a science of consciousness - the first Tucson discussions and debates. Tucson, AZ: MIT; 1996. p.50-657.

14. Gewolb IH, Vice FL. Abnormalities in the coordination of respiration and swallow in preterm infants with bronchopulmonary dysplasia. Dev Med Child Neurol. 2006;48:595-9.

15. Gewolb IH, Vice FL. Maturational changes in the rhythms, patterning, and coordination of respiration and swallow during feeding in preterm and term infants. Dev Med Child Neurol. 2006;48:589-94.

16. Hanlon MB, Tripp JH, Ellis RE, Flack FC, Selley WG, Shoesmith HJ. New York deglutition apnea as indicator of maturation of suckles feeding in bottle-fed preterm infants. Dev Med Child Neurol. 1997;39:534-42.

17. Hirst LJ, Ford GA, Gibson GJ, Wilson JA. Swallow-induced alterations in breathing in normal older people. Dysphagia. 2002;17:152-61.

18. Hiss SG, Treole K, Stuart A. Effects of age, gender, bolus volume, and trial on swallowing apnea duration and swallow/respiratory phase relationships of normal adults. Dysphagia. 2001;16:128-35.

19. Hiss SG, Strauss M, Treole K, Stuart A, Boutilier S. Swallowing apnea as a function of airway closure. Dysphagia. 2003;18:293-300.

20. Hiss SG, Strauss M, Treole K, Stuart A, Boutilier S. Effects of age, gender, bolus volume, bolus viscosity, and gustation on swallowing apnea onset relative to lingual bolus propulsion onset in normal adults. J Speech Lang Hear Res. 2004;47:572-83.

21. Jafari S, Prince RA, Kim DY, Paydarfar D. Sensory regulation of swallowing and airway protection: a role for the internal superior laryngeal nerve in humans. J Physiol. 2003;550(pt 1):287-304

22. Jeffrey HE, Page M, Post EJ, Wood AK. Physiological studies of gastro-esophageal reflux and airway protective responses in the young animal and human infant. Clin Exp Pharmacol Physiol. 1995;22:544-9.

23. Kelly BN, Huckabee ML, Jones RD, Frampton CM. Nutritive and non-nutritive swallowing apnea duration in term infants: implications for neural control mechanisms. Respir Physiol Neurobiol. 2006;154:372-8.
24. Kelly BN, Huckabee ML, Jones RD, Frampton CM. The early impact of feeding on infant breathing-swallowing coordination. Respir Physiol Neurobiol. 2007;156:147-53.

25. Klahn MS, Perlman AL. Temporal and durational patterns associating respiration and swallowing. Dysphagia. 1999;14:131-8.

26. Leslie P, Drinnan MJ, Ford GA, Wilson JA. Swallow respiratory patterns and aging: presbyphagia or dysphagia? J Gerontol A Biol Sci Med Sci. 2005;60:391-5.

27. Loch WE, Loch WE, Reiriz HM, Loch MH. Swallow apnea. Rhinomanometric manifestation and classification. Rhinology. 1982;4:179-91.

28. Martin BJ, Logemann JA, Shaker R, Dodds WJ. Coordination between respiration and swallowing: respiratory phase relationships and temporal integration. J Appl Physiol. 1994;76:714-23.

29. Martin-Harris B, Brodsky MB, Price CC, Michel Y, Walters B. Temporal coordination of pharyngeal and laryngeal dynamics with breathing during swallowing: single liquid swallows. J Appl Physiol. 2003;94:1735-43.

30. Martin-Harris B, Brodsky MB, Michel Y, Ford CL, Walters B, Heffner J. Breathing and swallowing dynamics across the adult lifespan. Arch Otolaryngol Head Neck Surg. 2005;131:762-70.

31. Martin-Harris B, Brodsky MB, Michel Y, Lee FS, Walters B. Delayed initiation of the pharyngeal swallow: normal variability in adult swallows. J Speech Lang Hear Res. 2007:50:585-94.

32. Miller AJ. Deglutition. Physiol Rev. 1982;62:129-84.

33. Nishino T, Yonezawa T, Hon DA. Effects of swallowing on the pattern of continuous respiration in human adults. Am Rev Respir Dis. 1985;6:1219-22.

34. Nishino T. [Interaction of swallowing and control of breathing]. Nihon Kyobu Shikkan Gakkai Zasshi. 1990;28:16-21.

35. Patten BM. Development of the digestive and respiratory systems. In: Patten BM, editor. Human embryology. New York: Blakiston; 1953. p.460-98.

36. Preiksaitis HG, Maayrand S, Robins K, Diamant NE. Coordination of respiration and swallowing: effect of bolus volume in normal adults. Am J Physiol. 1992;263:624-30.

37. Preiksaitis HG, Mills CA. Coordination of breathing and swallowing: effects of bolus consistency and presentation in normal adults. J. Appl Physiol. 1996;81:1707-14

38. Presman JJ. Sphincter action of the larynx. Arch Otolaryngol 1941:33:351-77.

39. Pressman JJ, Kelemen G. Physiology of the larynx. Physiol Rev. 1955;35:506-54

40. Rempel G, Moussavi Z. The effect of viscosity on the breath-swallow pattern of young people with cerebral palsy. Dysphagia. 2005;20:108-12.

41. Ren J, Shaker R, Zamir Z, Doods WJ, Hogan WJ, Hoffmann RG. Effect of age and bolus variables on the coordination of the glottis and upper esophagea sphincter. Am J Gastroenterol. 1993;88:665-9.

42. Selley WG, Flack FC, Ellis RE, Brooks WA. Respiratory pattern associated with swallowing: Part 1. The normal adult pattern and changes with age. Age Ageing. 1989;18:168-72.

43. Shaker R, Li Q, Ren J, Townsend WF, Dodds WJ, Martin BJ, Kern MK, Rynders A. Coordination of deglutition and phases of respiration: effect of aging, tachypnea, bolus volume, and chronic obstructive pulmonary disease. Am J Physiol. 1992;263:750-5.

44. Shaker R, Dua KS, Ren J, Xie P, Shi AF, Schapira RM. Vocal cord closure pressure during volitional swallow and other voluntary tasks. Dysphagia. 2002;17:13-8.

45. Smith J, Wolkove N, Colacone A, Kreisman H. Coordination of eating, drinking and breathing in adults. Chest. 1989;3:578-82.

46. Thach BT. Maturation and transformation of reflexes that protect the laryngeal airway from liquid aspiration from fetal to adult life. Am J Med. 2001;111 69-77.

47. Thach BT. Can we breathe and swallow at the same time? J Appl Physiol. 2005;99:1633.

48. Wilson SL, Hach BT, Broillette RT, Abu-Osba YK. Coordination of breathing and swallowing in human infants. J Appl Physiol. 1981;50:851-8.

Received 13/11/2008 Accepted 20/7/2009. 